\title{
TOXICOLOGICAL-HYGIENIC INVESTIGATIONS OF NEW PESTICIDES FROM THE POSITION OF OCCUPATIONAL RISIK ASSESSMENT
}

\section{Yastrub T. A.}

\section{State Institution «Kundiiev Institute of Occupational Health of the National Academy of Medical Sciences of Ukraine», Kyiv}

Introduction. The increase in the range of plant protection products necessitates the creation of highly reliable methods of hygienic evaluation of working conditions and potential risks as a tool for monitoring inhalation and dermal exposure.

Purpose of the study - analytical assessment of scientific developments in toxicological and hygienic research of pesticides, methodological approaches to definition of occupational risk and improvement of practice of their use in Ukraine.

Materials and methods. Standards, sanitary norms, other normative documents of the national legislation, regulating the safe use of pesticides; international standards and legislation of the European Union (EU) on pesticide risk assessment and a procedure of approval of their placing on the market of plant protection products. The theoretical methods of scientific research in the field of toxicology and safe use of pesticides, analytical estimation of modern approaches to definition of occupational risk, registration of pesticides and improvement of practice of their use in Ukraine have been used in this work. Results. In order to prevent harmful effects of pesticides on the human health, living organisms and the environment in each country, strict legal restrictions were introduced on their application. The procedure for registration of plant protection products is a matter of national security and should be solved at the state level. All drugs that are used should be thoroughly checked on compliance with the basic principles of protection against toxic effects of pesticides, namely: preventive sanitary supervision, distance protection, time protection, dose protection, risk assessment, mechanical protection means.

Conclusions. The fulfilment of the terms of the Association Agreement between Ukraine and the European Union provides for a set of measures for adaptation and implementation of the national regulatory framework in accordance with European legislation. Scientific developments in the study of peculiarities of pesticide effect on humans and the environment highlights the main task of occupational health - an objective quantitative assessment of working conditions, justification of safe levels of pesticide content in industrial facilities and development of methodological approaches to occupational risk assessment, taking into account the international, European and national experience.

Key words: pesticides, toxicological and hygienic assessment, prediction of occupational risk, normative-legal provision

\section{Introduction}

According to the Food and Agriculture Organisation of the United Nations (FAO), today's actual task is to solve the problem of the global hunger and provide the population with food products. However, the implementation of the potential of agricultural crops is impossible without using modern integrated plant protection systems, where the leading factor is a chemical method, which involves the scientifically based application of pesticides of different action.

Annually, there is a tendency to update the quantity and range of pesticides. As of 2018 , the «List of pesticides and agrochemicals approved for use in Ukraine» includes 2,769 preparations of domestic and foreign production [1].

In this regard, the development and implementation of hygienic standards and regulations on the safe use of pesticides is a guarantee of minimizing their harmful effect on the human health and the environment.

Based on the above, the purpose of this work was analytical assessment of scientific developments in toxicological and hygienic research on pesticides, methodological approaches to definition of occupational risk and improvement of practice of their use in Ukraine.

\section{Materials and methods of the study}

The materials of the research were standards, sanitary norms, other normative documents of the national legislation, regulating the safe use of pesticides; international standards and legislation of the European Union (EU) on risk assessment and authorization procedure for placing pesticides on the market of plant protection products. The theoretical methods of the scientific research in the field of toxicology and safe use of 
pesticides, analytical assessment of modern approaches to definition of occupational risk, registration of pesticides and improvement of practice of their use in Ukraine have been used in this work.

\section{Results of the study and discussion}

In Ukraine, the development of the problem of toxicology and safe use of pesticides began in the last century in the laboratory of toxicology of the Kiev Institute of Occupational Health and Occupational Diseases, created in 1929 under the leadership of Professor H. Shkavera - a representative of the school of N. P Kravkov, one of the most famous Soviet toxicologists. At that time, the fundamentals of a very important direction - toxicology of inorganic compounds of copper, arsenic, fluorine (P. A. Braginsky, G. F. Polak) and chemicals, used in agriculture, were laid, - toxicology of mercury organic fungicides (L. I. Medved), in particular.

The development of inorganic pesticides, such as arsenic, copper, mercury, sulfur-containing compounds, reached its highest level by 1932 . However, due to high toxicity to the warm-blooded, mercurycontaining and arsenic-containing pesticides were banned for application, and since the 40 s of the last century inorganic compounds were practically replaced by organic pesticides on the world market.

In the post second world war years, the study on toxicology of pesticides has become widespread. The toxic properties of DDT, hexachlorane, thiophos and other organochlorine, organophosphorus and nitrophenol pesticides were studied. In the 1960s, the study of derivatives of urea, thio - and dithiocarbamic acids began; new methods for assessing sensitizing, mutagenic properties of pesticides, their toxic effect on the reproductive function and development were introduced. During that period toxicological properties of more than 300 pesticides were investigated, there were established a number of new regularities, concerning the dependence of toxic, cumulative properties, the degree of resorption through the skin on the chemical structure of compounds (L. Medved, Yu. Kagan, O. Burkatska, E. Spynu, Yu. Kundiiev, V. Tsapko, V. Matyushina et al.).

Toxicological studies of pesticides were carried out in parallel with studying problems of safe use of pesticides. Developments in the study of peculiarities of pesticide effect on humans and the environment made it possible to determine the main characteristics of pesticides which distinguish them from other xenobiotics: regular targeted introduction in the environment, inevitability of circulation in the biosphere; high biological activity, deliberate destruction of living organisms; impossibility of using in completely safe quantities; contact with them of the wide population, inability to exclude individuals from contact.

These peculiarities, which for the first time were formulated by L. I. Medved, the founder of the national toxicology of pesticides and their safe use, determined the main task of occupational health - an objective quantitative assessment of working conditions and the need for an integrated approach to the hygienic rationing of pesticides in environmental objects.

In the combined approach to the hygienic regulation of pesticides for the population, the basic safety criterion is the Acceptable Daily Intake (ADI), which is an integral toxicological indicator of the safety of residual quantities of pesticides in food products, water and the atmospheric air.

In earlier studies on toxicology of pesticides, it was found that most organophosphorus compounds can penetrate the undamaged skin and cause toxic effect. In this regard, one of the priority tasks of scientists was to study the dependence of the degree of absorption of pesticides through the skin on their chemical structure and physico-chemical properties, to clarify mechanisms of penetration of pesticides through the skin and develop effective measures for prevention of poisonings, related to the use of organophosphorus pesticides. Thus, one more important direction of scientific studies was determined - dermal toxicology of pesticides, the founder of which was Y. I. Kundiev.

The results of studies, by which it was established a high probability of poisonings by organophosphorus pesticides on their application to the skin, allowed to develop better practice of hygienic regulation of chemicals in the working zone air. Since 1964, with the approval of maximum allowable concentrations (MACs) of chemicals, which can cause a pronounced skin and resorptive effect, a special symbol «dangerous when applied onto the skin» was introduced.

The generalized results of experimental toxicological and hygienic studies were the basis of the factual materialб presented in the monograph by Yu. Kundiiev «Absorption of pesticides through the skin and prevention of poisonings», which became a desk book for specialists studying toxicology of pesticides, and chemicals in general. 
ISSN 2223-6775, Ukrainian Journal of Occupational Health, 2019, 15 (1), 13-18

Based on the great experience, gained in prophylactic toxicology, thanks to the works by Yu. Kundiiev and his school in solving problems of hygienic standardization of the permissible level of chemicals for the skin, it is possible to ground a unified methodical approach for evaluation of skin resorptive action of pesticides, since the significance of this pathway in forming the total dose of a toxicant entering the body of workers from the objects of the production environment is actual in our times.

Further studies were carried out in direction of calculating the dermal exposure risk of pesticides for operators, working with pesticides at the stages of preparation of working formulation and spraying. The peculiarities of pollution of the production environment have been determined, depending on the stage of application of pesticides and the method of plant treatment; an algorithm of determination of the skin absorption dose for the quantitative estimation of occupational risk is developed. It has been shown that some of provisions of the methodology for assessing the risk of transcutaneous effects require further studies and scientific development [2].

This is due to the fact that modern pesticide preparations of different classes of organic compounds according to the parameters of dermal toxicity are referred mainly to moderate and low hazardous compounds, distinguishing them from organophosphorus pesticides, which have a pronounced skin-absorption action. In such conditions, the development of standards with the use of experimental studies on laboratory animals and a great range of pesticides is practically impossible and unreasonably costly.

The use of mathematical modeling of penetration of pesticides through the skin from the standpoint of the theory of diffusion has created an opportunity for a new approach to the hygienic standardization of pesticides for the skin. The principle of the method is in transformation of the internal permissible dose into the maximum permissible level of skin contamination using a calculated model of the coefficient of penetration of a substance through the skin [3].

The created mathematical models of quantitative determination of the permeability of chemical substances through the skin by their physical and chemical properties become the basis for solving practical problems of hygienic assessment of working conditions in the use of pesticides as an integral part of assessing the safety of pesticides for the human health and the environment at the stage of their preregistration period.
In order to prevent harmful influence of pesticides on the human health, living organisms and the environment in each country, strict legal restrictions have been introduced for their application $[4,5]$.

The World Health Organization (WHO), the Food and Agriculture Organization (FOA), the European Food Safety Authority (EFSA), the Codex Alimentarius, the US Environmental Protection Agency (EPA) play an important role in the field of preventive medicine, as well as their own methodological approaches to risk assessment.

In Ukraine, legal relations on the state testing and registration of pesticides and agrochemicals concerning safety for the human health and the environment are regulated by the Law of Ukraine No. 87/95-BP «On Pesticides and Agrochemicals», by Resolution № 295 «On Approval of the Procedure for conducting state tests, state registration and re-registration, publication of lists of pesticides and agrochemicals authorized for use in Ukraine» [6, 7].

All applied pesticides should be thoroughly checked and approved by the relevant public authorities, in compliance with the basic principles of protection against toxic effects of pesticides, namely: preventive sanitary supervision, distance protection, time protection, dose protection, risk assessment, mechanical protection means [8-10].

Legislative acts of the European Union (EU) and other civilized countries provide for risk assessment as an instrument for monitoring inhaled and dermal exposures and for making optimal management decisions in case of exceeding the Acceptable Operator Exposure Level (AOEL).

For prediction of exposure levels during mixing/ refueling (preparation of pesticide working solutions) and spraying plants prognosticated and calculated exposure models, officially recognized and verified in practice, are used [11-13]. The main elements of risk assessment models is the characteristics of harmful action of a pesticide on an individual, revealing the nature of dependence of such effect on the dose and determination of the exposure in real conditions of pesticide application.

The algorithm for calculating the risk level is in determining the ratio of the actual exposure dose, received during the treatment and calculated within the entire working time interval (standard terms of pesticide application) to the safe level (AOEL), which is determined from the results of subchronic and chronic experiments on animals. 
The results of expert-analytical and toxicologicalhygienic research of pesticides become the basis for development of hygienic norms and regulations for the safe use of pesticides, observance of which is a guarantee of promotion of occupational health and minimization of the influence on the natural environment [14].

In accordance with the current legislation of Ukraine, hygiene standards and regulations of the studied pesticides are approved by Orders of the Ministry of Health of Ukraine, registered with the Ministry of Justice for controlling by the State Service of Ukraine on Food Safety and Consumer Protection.

In general, the procedure for registration of plant protection products in Ukraine, which involves a number of ministries and departments, illustrates that this issue is of a national security and should be solved at the national level.

The execution of the terms of the Agreement on the association between Ukraine and the EU provides for a set of measures for adaptation and implementation of the national regulatory framework in accordance with the European legislation [15].

Thus, research institutes of toxicological and hygienic profile of the Ministry of Health of Ukraine and the National Academy of Medical Sciences of Ukraine are guided in their activity by normative and methodological documents of the Organization for Economic Co-operation and Development (OECD) on the conduct of toxicological, ecotoxicological studies as well as those concerning behavior of pesticides in the environment.

On the way to harmonization of international principles, criteria and methods of risk assessment, Ukrainian legal acts should include requirements for the content of dossiers submitted for the purpose of

\section{References}

1. Perelik pestytsydiv i agrokhimikativ, dozvolenykh do vykorystannya $\mathrm{v}$ Ukraini [List of pesticides and agrochemicals approved for use in Ukraine] (2018), Ministry of Ecology and Natural Resources of Ukraine, Univest Media LLC, Ukraine.

2. Kundiiev Yu. I.,Kirsenko V. V. and Yastrub T. O. (2007), "Determination of threshold limit values of skin contamination with the use of the skin penetration coefficient", Sovremennye problemy toksikologii, 2, $45-49$.

3. Kirsenko V. V and Yastrub T. O. (2017), "Theoretical bases and practical use of a diffuse model in penetration of chemicals through the skin", Ukrainian Journal of Occupational Health, 1, 14-23. registration of plant protection products, and normative and / or methodological documents should contain requirements for evaluation and decision making in registration of such tools [16].

Further scientific work on the safety of pesticides for operators, for individuals engaged in the treated areas and the population provides for development of measures on adoption of uniform principles, recommended by European guiding documents, since, as it is mentioned in the Law of Ukraine «On pesticides and agrochemicals» № 86 / 95-VR: «The main principle of the state policy in this area is the priority of promotion of the human health and the natural environment as compared to the economic effect from the use of pesticides and agrochemicals».

\section{Conclusions}

Pesticides represent a heterogeneous group of substances which are regularly and purposefully introduced in the environment and can harm biological systems. The increase of the range of plant protection products necessitates development of highly reliable prognosticated methods for hygienic assessment of working conditions and potential risks as a tool for monitoring inhalation and dermal exposures.

Scientific developments in the study of peculiarities of pesticide action on humans and the environment are focused on the decision of the main task of occupational health - an objective quantitative assessment of working conditions, justification of safe levels of pesticide content in industrial facilities and development of methodological approaches to occupational risk assessment taking into account the international, European and national experience.

4. REGULATION (EC) No 1107/2009 of the European Parliament and of the Council of 21 October 2009 concerning the placing of plant protection products on the market and repealing Council Directives 79/117/ EEC and 91/414/EEC, available at: https://eur-lex. europa.eu/LexUriServ/LexUriServ.do?uri=OJ:L:2009:3 09:0001:0050:EN:PDF.

5. How pesticides are regulated in the EU EFSA and the assessment of active substances, available at: https: / / www.efsa.europa.eu/sites /default/files / corporate_publications/files / Pesticides-ebook180424.pdf

6. "About pesticides and agrochemicals" (1995), Law of Ukraine dated March 2, 1995, Visnyk Verkhovnoi Rady Ukrainy, 14, p. 91. 
ISSN 2223-6775, Ukrainian Journal of Occupational Health, 2019, 15 (1), 13-18

7. On approval of the Procedure for carrying out state tests, state registration and re-registration, publication of lists of pesticides and agrochemicals approved for use in Ukraine (as amended): the resolution of the Cabinet of Ministers of Ukraine, March 4, 1996, № 295, available at: https://zakon.rada.gov.ua/laws/show/295-96-\%D0\%BF.

8. European Commission 2001. Acceptable operator levels (doc.7531/VI/95), 10 September 2001, available at: http://europa.eu.int/comm/food/protection/resources/publications en.htm.

9. Compiled comments from Member States and ECPA for the Guidance Document on the setting of acceptable operator exposure levels (AOELs) rev. 9, Sanco/10182/2005 rev. 9 from 5 July 2005.

10. European Commission Health and Consumer Protection Directorate-General (2006), Directorate E Safety of the Food Chain/ E3-Chemicals, Contaminants, Pesticides. Guidance foe Setting and Application of Acceptable Operator Exposure Levels (AOELs), 1-28.

11. Martin A. D. (1990), "A predictive model for the assessment of dermal exposure to pesticides", in Prediction of Percutaneous Penetration. Methods, Measurements, Modelling, Scott R. C., Guy R. H., Hadgraft J. (Eds), IBC Technical Services Ltd, Southampton, Hampshine, UK, 273-278.
12. Lundehn J. R.,Westphal D., Kieczka H., Krebs B., Löcher-Bolz S., Maasfeld W. and Pick E. D. (1992), "Uniform principles for safeguarding the health of applicators of plant protection products", Mitteilungen aus der Biologischen Bundesantalt für land-und Forstwirtschaft, heft 277, Berlin, Germany, 60-111.

13. EFSA (European Food Safety Authority), 2014, "Guidance on the assessment of exposure of operators, workers, residents and bystanders in risk assessment for plant protection products", EFSA Journal, 12 (10), 3874, 55 pp. https://doi.org/10.2903/j.efsa.2014.3874.

14. Kirsenko V., Yastrub T. and Kovalenko V. (2014), "Substantiation of regulations on the safe use of fungicide" Sillite, 400 SC" (a. i. dodin, 400 g/l) on apple trees», Ukrainian Journal of Occupational Health, 1, 66-73.

15. On Partnership and Cooperation between Ukraine and the European Community and its Member States: Agreement dated 16.06. 1994, available at: http:// zakon2.rada.gov.ua/laws/show/998_012.

16. Prodanchuk M., Sergeyev S., Lepioshkin L. et al. (2015), Analysis of registration requirements to occupational and public health safety at plant protection products application in the EU and Ukraine (a review of the legal and scientific-methodical documents), Modern problems of toxicology, food and chemical safety, 3, 5-13.

\title{
ястру6 т. 0.
}

\section{ТОКСИКОЛОГО-ГІГІЕНІЧНІ АОСАІАЛКЕННЯ НОВИХ ПЕСТИЦИАІВ З ПОЗИШЙ ОШНКИ ПРОФЕСІЙНОГО РИЗИКУ}

\author{
Аержавна установа «Інститут медицини праші імені Ю. І. Кундієва Нашіональної академії медичних наук \\ України», м. Київ
}

Bcmyn. Збільшення асортименту засобів захисту рослин обумовлює необхідність створення високонадійних методів гігієнічної оцінки умов праці та потенційних ризиків як інструменту моніторингу інгаляційних і дермальних експозицій. Мета дослідження - аналітична оцінка наукових розробок з токсиколого-гігієнічних досліджень пестицидів, методичних підходів до визначення професійного ризику та удосконалення практики їхнього використання в Україні.

Матеріали та методи дослідження. Матеріалами досліджень були державні стандарти, санітарні норми, інші нормативні документи національного законодавства, які регламентують безпеку пестицидів при їхньому застосуванні; міжнародні стандарти та законодавчі акти Европейського Союзу з оцінки ризику пестицидів і дозвільної процедури щодо їхнього розміщення на ринку засобів захисту рослин. У дослідженні використано теоретичні методи наукових розробок у галузі токсикології та гігієни застосування пестицидів, аналітичну оцінку сучасних підходів до визначення професійного ризику, реєстрації пестицидів і вдосконалення практики їхнього використання в Україні.

Результати. Для запобігання шкідливого впливу пестицидів на здоров’я людини, живі організми та довкілля в кожній країні введено жорсткі законодавчі обмеження щодо їхнього застосування. Процедура реєстрації засобів захисту рослин є питанням національної безпеки і повинна вирішуватися на державному рівні. Усі використовувані препарати повинні проходити ретельну перевірку на дотримання основних принципів захисту від токсичного впливу пестицидів, а саме: захист відстанню, захист часом, захист дозою, оцінка ризику, захист механічними способами.

Висновки. Виконання умов угоди щодо Асоціації між Україною та Європейським Союзом передбачає комплекс заходів з адаптації та імплементації національної нормативно-правової бази відповідно до європейського законодавства. Наукові розробки в напрямі дослідження особливостей впливу пестицидів на людину та навколишнє природне середовище визначають основне завдання гігієнічної науки - об’єктивну кількісну оцінку умов праці, обгрунтування безпечних рівнів вмісту пестицидів в об’єктах виробничого середовища та розробку методичних підходів до оцінки професійного ризику з урахуванням міжнародного, європейського та вітчизняного досвіду.

Ключові слова: пестициди, токсиколого-гігієнічна оцінка, прогнозування професійного ризику, нормативно-правове забезпечення 
Ястру6 T. A.

\section{ТОКСИКОЛОГО-ГИГИЕНИЧЕСКИЕ ИССАЕАОВАНИЯ НОВЫХ ПЕСТИЧИАОВ С ПОЗИЧИИ ОЧЕНКИ ПРОФЕССИОНАЯЬНОГО РИСКА}

Государственное учрежАение «Институт медишины труда имени Ю. И. Кундиева Национальной академии медицинских наук Украины», г. Киев

Введение. Увеличение ассортимента средств защиты растений обусловливает необходимость создания высоконадежных методов гигиенической оценки условий труда и потенциальных рисков как инструмента мониторинга ингаляционных и дермальных экспозиций.

Цель исследования - аналитическая оценка научных разработок по токсиколого-гигиеническим исследованиям пестицидов, методических подходов к определению профессионального риска и усовершенствование практики их использования в Украине.

Материалы и методы исследования. Материалами исследований были государственные стандарты, санитарные нормы, другие нормативные документы национального законодательства, регламентирующие безопасность пестицидов при их применении; международные стандарты и законодательные акты Европейского Союза (ЕС) по оценке риска пестицидов и разрешительной процедуре по их размещению на рынке средств защиты растений. В работе использованы теоретические методы исследования научных разработок в области токсикологии и гигиены применения пестицидов, аналитическая оценка современных подходов к определению профессионального риска, регистрации пестицидов и усовершенствованию практики их использования в Украине.

Pезультаты. Для предотвращения вредного воздействия пестицидов на здоровье человека, живые организмы и окружающую среду в каждой стране введены жесткие законодательные ограничения по их применению. Процедура регистрации средств защиты растений является вопросом национальной безопасности и должна решаться на государственном уровне. Все используемые препараты должны проходить тщательную проверку на соблюдение основных принципов защиты от токсического воздействия пестицидов, а именно: защита расстоянием, защита временем, защита дозой, оценка риска, защита механическими способами.

Bыводы. Выполнение условий соглашения об Ассоциации между Украиной и Европейским Союзом предусматривает комплекс мер по адаптации и имплементации национальной нормативно-правовой базы в соответствии с европейским законодательством. Научные разработки в направлении исследования особенностей влияния пестицидов на человека и окружающую природную среду определяют основную задачу гигиенической науки - объективную количественную оценку условий труда, обоснование безопасных уровней содержания пестицидов в объектах производственной среды и разработку методических подходов к оценке профессионального риска с учетом международного, европейского и отечественного опыта.

Ключевые слова: пестициды, токсиколого-гигиеническая оценка, прогнозирование профессионального риска, нормативно-правовое обеспечение

ORCID ID of author of the paper:

Yastrub T. A. (0000-0002-5084-3773).

Information on the research funding source: the research was funded by the «Quantative definition of dermal absorption of pesticides in organisms of the environmental objects and the risk of their harmful effects on humans», № state registration $0117 \mathrm{U} 000664$.

Надійшла: 19 грудня 2018 р.

Контактна особа: Яструб Тетяна Олександрівна, лабораторія токсикології пестицидів та гігієни праці при їх застосуванні, ДУ «Інститут медицини праці імені Ю. І. Кундієва НАМН України», буд. 75, вул. Саксаганського, м. Київ, 01033. Тел.: + 380442894274. 